\title{
Investigation of the Leadership Qualifications of School Managers in Educational Administration: The Teachers' Views

\author{
Salih Sarışık
}

\section{ARTICLE INFO}

Article History:

Received 29.12.2019

Received in revised form

06.06.2020

Accepted

Available online 01.10.2020

\begin{abstract}
In this study, it is aimed to determine the efficiencies of school managers in educational administration by getting teacher opinions. The research's field of study includes totally 40 teachers ( 21 female , 19 male ) who works in Sapanca, Sakarya: 10 pre-school teachers, 10 primary school teachers, 10 secondary school teachers and 10 high school teachers. In the e search, teachers were asked 6 questions to find the proficiencies of school managers in educational administration by getting teacher opinions. Since the interviews were made in computer environment, they were recorded digitally and then turned into written documents. At the end of the research, the proficiencies of school managers in educational administration according to the teacher opinions were evaluated under 6 titles. It was mostly declared by the teachers that managers should be fair. When evaluated as academically, it was stated that they should support the students and give importance to education more than enough hand also was mostly declared that they should motivate and award the students to improve their academic success. In terms of social activities, it was stated that they should provide all kind of opportunities by the personal differences of the students. Finally, when evaluated as their attitudes towards teachers, it was indicated that they should be fair, respectful managers who can communicate well.
\end{abstract}

(C) IJERE. All rights reserved

Keywords: ${ }^{1}$

Leadership, Manager, School, Teacher, Student.

\section{INTRODUCTION}

The functioning purpose of the schools is to provide students with the desired behaviors and to ensure that they successfully graduate academically. In this context, the success of schools and principals is measured by the attainability of the goals. If the graduated students are successful, it means that the school and the principal have achieved their goals, if not, they have not achieved their goals. However, Glasser (1999) says that the students who started school did not fail, they learned the failure at school and they were labelled as unsuccessful. Being a successful student means that he / she has attained the essential know ledge and skills at the grade level he / she has been studying. Students who are successful and pass to the higher grade can be said to have sufficient know ledge and skills within the scope of the new grade level. When the student finishes her/his education life with a high degree and has a diploma, she/he will have financial and moral gains in his/her professional life with this diploma related to his/her field. Özcan (2006) stated that school principals with leadership skills have the ability and knowledge to bring teachers and students together in parallel with pre-determined goals and to motivate them. Leaders who do this task in schools are school principals. The Ministry of National Education defines school principals as leaders. This statement takes place as the first article in the "Job Descriptions of the Ministry of National Education Directorate of Primary Education" section in the Journal of Communiqué No 2508 published in 2000. When considered from this point of view, school principals are considered as leaders rather than managers and they have played crucial roles in students' academic success.

The duties of the school principals are clearly defined by law and while performing these duties, they quickly find solutions in unusual situations encountered and effectively implement these solutions in line with the certain goals (Taymaz, 2003 ). School principals played a key role in the development of schools. In this context, they have to ensure coordination between people who are experts in different fields (Balc1, 2007). In order for this to happen, school principals need to develop themselves and specialize in many areas. It is thought that the success of school principals in ensuring coordination will increase the success of students. It is stated that the leadership competence of school principals are accepted as an important factor in determining the quality of teacher and learning in schools. As the leader of the institution, the principal has to prepare the environment needed for the success of the students and the desired education.

${ }^{1}$ Corresponding e-mail:salih.sarisik@ogr.sakarya.edu.tr, orcid.org/0000-0002-6506-2830, Ministry of Education 
It is the responsibility of school principals to adapt the physical conditions of the school, to ensure achievements in education, to increase the academic success and prefer ability of the school by communicating effectively with students and teachers. The duties of school principals specified in the TALIS report regarding management are as follows: To manage the activities determined in accordance with the goals of the school, to be effective in the professional development of teachers, to evaluate the education and training activities of teachers and their results, to ensure the effective implementation of formal works and processes (Organization for Economic Co-operation and Development (OECD, 2009). School principals are expected to demonstrate the characteristics of the concept of leadership, which is evaluated not only with its managerial qualities but also from different perspectives in field scanning (Beck \& Murphy, 1993). As the leader of the institution, a school principal must create an effective and hardworking team and have a good vision in order to direct his team properly. Being a leader emphasizes the importance of taking into consideration the issues related to students' psychological situations in a more result-oriented and effective way (Robinson, Lloyd \& Rowe, 2008).Leaders of schools should share this task with other staff, rather than transferring all their energy into official paperwork. Generates new ideas in terms of education, enables students and teachers to achieve goals, checks teachers and students and makes class visits without informing them and gives feedback, prepares and displays activities for the characteristics of the school, provides coordination among school administrators in order to reach the targets (Hull, 2012 \& Karagöz, 2018).

The influence and duties of the school principal are very important in determining and implementing the school culture in schools considered as the most basic unit of education and in the regular functioning of the education system in the countries (Bursalığlu, 2002; Murphy, 1998 ).Leadership aspects of school principals have a very important place in the adoption of school culture by administrators, teachers and students, in completing the functions of the institution completely and in achieving the determined goals ( Law \& Glover, 2000 ). Erdogan (2000) stated that for school principals, having necessary knowledge and skills are not sufficient, they should have some responsibilities such as measuring and evaluating the general and specially acquired knowledge, skills, behavior and values, organizing, developing and planning the curriculum. Again, Özden (1998) states that school principals' duties are to provide a positive educational environment in their schools, to emphasize the success of the students and to eliminate the negative behaviours happening in achieving the determined goals of the school. He also states that leading the teaching process is the fundamental duty of school principals. It can be seen that school principals have the responsibility at the schools that aim to reach certain goals. In this context, it can be said that one of the most important factors in the adequacy of schools is the principal, the leader (Goldberg, 2001).If the leader has little or no knowledge, and success of such a school is anything but a coincidence. Because the school will be shaped in a plan according to the leaders' thoughts and approaches. In this context, while the same rules and instructions are applied in all schools, the distinction between the success of the students, the way the teacher works and the parents' responses reveals how important the influence of the leader and the principal (Goldberg, 2001). There is a need for leaders who can effectively manage and control the developing technology and information flow in schools. Because leadership is very important in increasing the quality of education of educational institutions and academic success of students. Studies show that the difference between successful and unsuccessful schools is due to the success of leadership and school management at the beginning of education (Kalyoncu, 2008 ).

Successful school principals set specific and general goals for their institutions and trigger teachers to achieve these goals. Leaders are people who shape the goals, motivations and actions of others (Karagoz \& Ruzgar, 2020). Management, on the other hand, is trying to achieve its goals and educational activities successfully. In order for a school to achieve its goals and policies, it must have both concepts. School principals can contribute to the decision-making process by increasing their loyalty to the decisions taken and the belief in the target (Bush \& Glover, 2003). In the literature, the word manager is defined as the person who wants to make the employees feel the necessary information and experience that his/her position requires. The leader is the person who leads people to achieve the goals of organizations. The 
principal makes an effort to manage the schools with pre-determined conditions. The leader is the visionary who can make the changes needed to keep up with the differences (Ünal, 2012 ).

\section{Comparison of Leadership and Management (Table 1)}

\begin{tabular}{cc}
\hline MANAGER & LEADER \\
Manages & Directs \\
Maintains the current order & In pursuit of innovations \\
The authority originates from his/her & Has self-discipline \\
position & \\
Holds the power in his/her hands & Authorizes her/his inferiors \\
Emphasizes obedience & Emphasizes participation \\
Highly sticks to plans & Open to alternative approaches \\
Serves the certain goals & Creates new goals \\
Does the work right & Does the right job \\
Emphasizes control & Emphasizes mutual trust
\end{tabular}

Source: Özden, Y. (2005), New Values in Education- Transformation in Education. Ankara: Pegem A Publishing.

Effective school leaders should keep their employees' morale and motivation at the highest level. They must act as a role model for the teachers and affect the teachers positively with their good manners and behaviours. They must treat equally and fairly to the school staff. They must work diligently to solve the problems and must be open to criticism. School Principals are aware that it is impossible for everyone to agree with them and conveys different approaches to teachers in an appropriate way (Duman \& Karagöz, 2016; McEwan, 2018 ). It is of great importance that how the management policies and leadership competencies of the school principals are understood by teachers and the reflection of this on the work environment (Cerit, 2008:5 ). With this research, it was aimed to determine the leadership competencies of teachers and school principals in educational management and to determine the leadership qualities that school principals must have.

What are the leadership competencies of school principals in educational management? The aim of the research is to determine the competencies that must be found in school principals as leaders in line with the opinions of teachers. Since the number of researches that directly address the relationship between school administrators' educational management and leadership characteristics is very limited, this research is thought to make an important contribution to the relevant literature. In addition, it is also important that the research is directed to managers and teachers working at compulsory education levels, which are at the important point of the education system and where all the skills and behaviors required during the life of the person are gained. To investigate the level of perception of the leadership behaviors of school principals in educational management by employees and to determine the relationship between this perception and visionary leadership, it is thought that it will contribute significantly to the development of leadership behaviors of managers and their efforts to improve their managerial skills in general.

\section{METHOD}

In the research, the semi-structured interview technique, one of the qualitative research methods, was used which is defined as "the research in which qualitative data collection methods such as observation, interview, document analysis are used, and a qualitative process is followed to reveal perceptions and events in a realistic and holistic way in the natural environment" ( Yıldırım \& Şimşek, 2008 ). In the research, the interview form, which was developed in order to determine the teachers' opinions about the leadership competencies of the educational administrators, was pu into its final form in line with the opinions of the teachers, taking into consideration the gender, age, year of seniority and the grades that they have worked. There are six open-ended questions in the interview form. In the educational management of teachers, the opinions of the principals about leadership competencies were tried to be determined.

\section{Data Collection Tool}

In the research, interview form was used as a data collection tool. During the preparation phase of the interview questions, the literature was analyzed and 6 open-ended questions that would best express the relevant sub-problems were prepared and written on the interview form. Open-ended research questions 
"provide the researcher with an flexible and open-ended approach to what she/he wants to analyze" ( Yıldırım \& Şimşek, 2008 ).

The interviews were held on the dates and times determined according to the school hours of the teachers. The interviews were written and recorded on the computer in order to avoid data loss.

\section{Data Analyses}

The data obtained from the interviews were analyzed by descriptive analysis method. Descriptive analysis consists of four stages: creating a framework for descriptive analysis, processing data according to the thematic framework, defining findings and interpreting the findings (Ylldırım \& Şimşek, 2008 ). The thematic framework was determined by the researchers for the analysis of the data. In this context, the data were first coded individually by each researcher. Then, the data gathered were compared and common codings were made in common themes in consensus. The findings are arranged in tables. The teachers interviewed are coded starting from $\mathrm{T} 1$ to T40. In the interpretation of the findings, direct quotations from the opinions of the teachers were included.

\section{FINDINGS}

In this section, the findings obtained from the research are included.

The Teachers' Viewson The School Managers' Leadership Qualifcations In Educational Administration The views of school principals about the analyzing of leadership competencies in educational management in line with the opinions of teachers are shown in tables below.

The opinions of the teachers on the personality characteristics of the leader school principal are presented in Table 2.

Table 2. Teachers' views on the personality characteristics of the leading principal

\begin{tabular}{clcc}
\hline Theme (Categories) & \multicolumn{1}{c}{ Codes } & $n$ & $\%$ \\
\hline & Fair (T8,T14,T15,T16,T17,T23,T25,T26,T32,T35,T36,T37,T38) & 13 & 32,5 \\
& Innovative(T3,T12,T13,T18,T19,T20,T23,T27,T37) & 9 & 22,5 \\
& Honest(T1,T5,T8,T10,T14,T15,T28,T31) & 8 & 20 \\
& Tolerant(T5,T8,T14,T20,T22,T34) & 6 & 15 \\
& Indulgent (T6,T7,T10,T20,T24,T34) & 6 & 15 \\
& Self-confident (T4,T11,T12,T18,T24) & 5 & 12,5 \\
& A good Listener (T6,T11,T28,T33,T38) & 5 & 12,5 \\
Personality & Respectful (T3,T31,T39,T40) & 4 & 10 \\
characteristics of the & Consistent (T4,T16,T39,T40) & 4 & 10 \\
leading school principal & Solution oriented (T8,T16,T21,T23) & 4 & 10 \\
& Reliable (T15,T25,T27) & 3 & 7,5 \\
& Self-controlled (T1,T39,T40) & 3 & 7,5 \\
& Responsible (T2,T17,T27) & 3 & 7,5 \\
& Being Egoless(T2,T7,T23) & 3 & 7,5 \\
& Hardworking (T3,T16,T28) & 3 & 7,5 \\
& Objective (T5,T30,T36) & 3 & 7,5 \\
& Empathetic (T6,T22,T26) & 3 & 7,5 \\
& Good at Organizing (T8,T9,T27) & 3 & 7,5 \\
& Open to communication (T11,T12,T31) & 3 & 7,5 \\
& Disciplined (T18,T19,T25) & 2 & 5 \\
\cline { 2 - 4 }
\end{tabular}

When Table 2 is analyzed, teachers' opinions about the personality characteristics of the leader school principal; it was observed that it was at the most32.5\% as fair. Other opinions are as follow: $22.5 \%$ innovative, $20 \%$ honest, $15 \%$ tolerant and indulgent, $12,5 \%$ self-confident and a good listener, $10 \%$ respectful, consistent and solution oriented, 7,5\% reliable, self-controlled, responsible, being egoless, hardworking, objective, empathetic, good at organizing, open to communication and $5 \%$ disciplined. The exact quotations taken from the opinions of the teachers are presented below.

"He/she must be good at organizing, solution-oriented, mind full of equality and honesty, tolerant and smiling."(T8) 
"Compassionate, self-confident, following innovations, improving themselves, having strong human relations, able to communicate."(T12)

"He/she must be self-aware and be aware his/her abilities, be honest, reliable and fair. He/she must have the ability of persuasion."(T15)

"She/he must be patient, empathetic, tolerant, and responsible."(T22)

"She/he must be tolerant and understanding towards her employees."(T34)

The opinions of the teachers about the managerial characteristics of the leader school principal are presented in Table 3.

Table 3. Teachers' views on the managerial characteristics of the leader school principal

\begin{tabular}{clcc}
\hline \multicolumn{1}{c}{ Codes } & $n$ & $\%$ \\
\hline Theme (Categories) & & 12 & 30 \\
& Fair (T2,T5,T10,T11,T12,T19,T20,T24,T26,T29,T37,T38) & 8 & 20 \\
& Collaborator(T3,T4,T7,T15,T16,T33,T35,T37) & 6 & 15 \\
& Ingenious(T5,T21,T22,T23,T28,T31) & 5 & 12,5 \\
& Motivating (T6,T11,T17,T26,T27) & 5 & 12,5 \\
& Innovative(T12,T13,T17,T35,T37) & 5 & 12,5 \\
& Honest (T11,T18,T21,T27,T36) & 5 & 12,5 \\
Management features of & Has the knowledge of the legislation(T15,T28,T32,T39,T40) & 4 & 10 \\
the leader school & Has a vision(T11,T12,T16,T23) & 3 & 7,5 \\
principal & Determined(T2,T8,T30) & 3 & 7,5 \\
& Hardworking(T14,T25,T29) & 3 & 7,5 \\
& Reliable(T18,T23,T27) & 3 & 7,5 \\
& Tolerant (T27,T34,T38) & 3 & 7,5 \\
& Education oriented(T10,T16) & 2 & 5 \\
& Principled(T20,T28) & 2 & 5 \\
& Polite(T35,T39) & 2 & 5 \\
& Smiling(T38,T39) & 2 & 5 \\
& Sensitive (T1) & 1 & 2,5 \\
& Disciplined (T8) & 1 & 2,5 \\
& Has a spirit of Sharing (T9) & 1 & 2,5 \\
\hline
\end{tabular}

When Table 3 is analyzed, teachers' opinions about the managerial features of the leader school principal, it was observed that it was at the most 30\%as fair. Other opinions are as follow: $20 \%$ collaborator, $15 \%$ ingenious, $12,5 \%$ motivating, innovative, honest and has the knowledge of the , $10 \%$ has a vision, $7,5 \%$ be a model, determined, hardworking, reliable and tolerant, 5\% education oriented, principled, polite and smiling, 2,5\% sensitive, disciplined and has a spirit of sharing. The exact quotations taken from the opinions of the teachers are presented below.

"When it comes to referring and management, Helshe must be fair and education-oriented, not perform the tasks to make up to someone."(T10)

"He/she must be sensitive to the employees, who can manage time and himself/herself, behave as a role model"(T3)

"He /she must be ingenious and must not to details. He/she protects everyone' interest and does the tasks at the same time"(T5)

"He/she must be tolerant, empathetic, understanding, motivating, honest and reliable."(T27)

"He/she must keep up with the technology, believe in equality and justice and must be collaborative."(T37) 
The opinions of the teachers on the educational activities of the leader school principal are presented in Table 4.

Table 4. Teachers' views on the educational activities of the leader school principal

\begin{tabular}{|c|c|c|c|}
\hline Theme (Categories) & Codes & $n$ & $\%$ \\
\hline \multirow{16}{*}{$\begin{array}{c}\text { Educational activities of } \\
\text { the leader school } \\
\text { principal }\end{array}$} & Supportive for students (T13,T15,T20,T21,T23,T24,T30,T31,T33) & 9 & 22,5 \\
\hline & Take Education as apriority(T7,T9,T23,T24,T29,T34,T37,T39) & 8 & 20 \\
\hline & Supportive for teacher (T3,T4,T10,T12,T20,T24,T31,T37) & 8 & 20 \\
\hline & Experienced (T4,T10,T18,T38,T39,T40) & 6 & 15 \\
\hline & Have full knowledge of the system(T8,T18,T22,T38,T39,T40) & 6 & 15 \\
\hline & Collaborator (T17,T19,T22,T26,T28) & 5 & 12,5 \\
\hline & Innovator $(\mathrm{T} 1, \mathrm{~T} 6, \mathrm{~T} 8, \mathrm{~T} 16, \mathrm{~T} 36)$ & 5 & 12,5 \\
\hline & Provider (T3,T21,T35) & 3 & 7,5 \\
\hline & Inspector (T8,T11,T12) & 3 & 7,5 \\
\hline & Self-improving (T11,T16,T36) & 3 & 7,5 \\
\hline & Outgoing(T19,T27, T38) & 3 & 7,5 \\
\hline & Realistic (T15,T7) & 2 & 5 \\
\hline & Principled (T11,T32) & 2 & 5 \\
\hline & Using technology (T1) & 1 & 2,5 \\
\hline & Researcher (T3) & 1 & 2,5 \\
\hline & Motivate the others (T27) & 1 & 2,5 \\
\hline
\end{tabular}

When Table 4 is analyzed, teachers' opinions about the educational activities characteristics of the leader school principal, it was observed that it was at the most $22,5 \%$ as supportive for students. Other opinions are as follow: $20 \%$ take education as a priority and supportive for teacher, $15 \%$ experienced and have full knowledge of the system, 12,5\% collaborator and innovator, 7,5\% provider, inspector, self-improving and outgoing, 5\% realistic and principled, 2,5\% using technology, researcher and motivate. The exact quotations taken from the opinions of the teachers are presented below.

"Support student-centered education, motivate students by giving rewards."(T15)

"Supports the idea that education comes first."(T9)

"Disciplined, entrepreneur, supportive for teachers and educators, has a broad vision."(T12)

"Has full know ledge about education and training activities."(T18)

"Have knowledge and equipment related to the field of the institution in the institution where he / she works."(T40)

The opinions of the teachers on the academic success of students of the leader school principal are presented in Table 5.

Table 5. Teachers' views on the academic success of students of the leader school principal

\begin{tabular}{clcc}
\hline $\begin{array}{c}\text { Theme } \\
\text { (Categories) }\end{array}$ & \multicolumn{1}{c}{ Codes } & $n$ & $\%$ \\
\hline & Likes to reward & 13 & 32,5 \\
& others(T5,T17,T23,T24,T25,T30,T31,T34,T35,T36,T37,T38,T39) & 10 & 25 \\
& Motivate (T3,T5,T6,T10,T11,T12,T20,T24,T31,T39 & 9 & 22,5 \\
& Ensure the environment(T2,T7,T10,T12,T15,T19,T27,T33,T40) & 9 & 22,5 \\
The effect of & Supportive(T3,T7,T8,T10,T13,T14,T21,T33,T36) & 7 & 17,5 \\
the leader & Supporter(T9,T12,T22,T26,T32,T36,T37) & 4 & 10 \\
school & Collaborator(T1,T4,T14,T29,T33) & 4 & 10 \\
principal on & Interested (T20,T30,T34,T38) & 3 & 7,5 \\
academic & Be a role model(T2,T18,T23) & 3 & 7,5 \\
success of & Fair(T3,T5,T16) & 3 & 7,5 \\
students & Analyser (T8,T16,T22) & 3 & 7,5 \\
& Innovator (T14,T27,T31) & 2 & 5 \\
& Promoter (T23,T25) & 1 & 2,5 \\
& Reliable (T11) & 1 & 2,5 \\
\hline & Humanist (T28)
\end{tabular}


When Table 5 is analyzed, teachers' opinions about the academic success characteristics of the leader school principal, it was observed that it was at the most $32,5 \%$ as rewarding manager. Other opinions are as follow: $25 \%$ motivate, $22,5 \%$ ensure the environment and supporting, $17,5 \%$ following, $10 \%$ collaborator and interested, 7,5\% role model, fair, analyzer and innovator, $5 \%$ promoter, $2,5 \%$ reliable and humanist. The exact quotations taken from the opinions of the teachers are presented below.

"Provides equality in opport unities, loving, motivating as much as possible." (T5)

"Produces extra curricular academic projects, motivates and rewards students."(T31)

"Prepares the appropriate learning environment, passionate and exemplary."(T2)

"Provide then ecessary facilities to teachers."(T21)

"Must be someone who closely monitors the work and rewards students and support teachers."(T36)

The opinions of the teachers on the social activity the leader school principal are presented in Table 6 .

Table 6. Teachers' views on the social activity of the leader school principal

\begin{tabular}{clcc}
\hline Theme (Categories) & \multicolumn{1}{c}{ Codes } & $n$ & $\%$ \\
\hline & Caring(T1,T4,T5,T6,T7,T9,T10,T13,T17,T23,T24,T32,T34,T37) & 14 & 35 \\
& Supportive(T3,T7,T8,T10,T11,T12,T14,T15,T18,T22,T23,T39,T40) & 13 & 32,5 \\
& Tolerative(T12,T15,T25,T26,T28,T30,T35,T37,T39,T40) & 10 & 25 \\
& Deals with arts and sports (T3,T23,T27,T30,T31,T36,T38) & 7 & 17,5 \\
The effect of the & Stays up to date (T2,T11,T12,T14) & 4 & 10 \\
leader school & Encouraging (T8,T19,T28,T29) & 4 & 10 \\
principal on social & Active (T12,T20,T33) & 3 & 7,5 \\
activities & Polite (T31,T36) & 2 & 5 \\
& Role model(T3) & 1 & 2,5 \\
& Organizes tours(T5) & 1 & 2,5 \\
& Determined (20) & 1 & 2,5 \\
& Understanding (T31) & 1 & 2,5 \\
\cline { 2 - 4 }
\end{tabular}

When Table 6 is analyzed, teachers' opinions about the social activity characteristics of the leader school principal, it was observed that it was at the most 35\% as caring. Other opinions are as follow: $32,5 \%$ supportive, $25 \%$ tolerative, $17,5 \%$ deals with arts and sports, $10 \%$ stays up to date and encouraging, $7,5 \%$ active, $5 \%$ polite, $2,5 \%$ role model, organizes tours, determined and understanding. The exact quotations taken from the opinions of the teachers are presented below.

"For students to grow according to the moral and cultural value, they need to give opportunity to the activities that enable the to develop." (T1)

"To reach every student, social activities should be as important as academic success."(T7)

"Activities must be organized to make them happy regarding the students' capacity."(T25)

"They must be understanding and respect students' abilities."(T31)

"It is necessary to support social events, provide an environment, be active and open to innovations."(T12) 
The opinions of the teachers on the approach to teachers the leader school principal are presented in Table 7. Table 7. Teachers' views on the approach to teachers of the leader school principal

\begin{tabular}{clcc}
\hline Theme (Categories) & \multicolumn{1}{c}{ Codes } & $n$ & $\%$ \\
\hline & Fair (T1,T2,T4,T5,T7,T11,T12,T14,T15,T17,T19,T21,T22,T23,T24,T25,T26, & 27 & 67,5 \\
& T28,T29,T30,T31,T32,T33,T35,T36,T38,T39) & 11 & 27,5 \\
& Polite(T1,T3,T6,T10,T22,T30,T34,T35,T36,T39,T40) & 11 & 27,5 \\
& Outgoing(T2,T3,T8,T14,T15,T19,T21,T24,T30,T32,T33) & 9 & 22,5 \\
& Understanding(T3,T7,T8,T17,T20,T21,T31,T34,T38) & 9 & 22,5 \\
Leading school & Empathetic (T1,T12,T13,T14,T24,T27,T28,T31,T33) & 7 & 17,5 \\
principal to teachers & Supportive (T22,T23,T9,T18,T25,T27,T32) & 3 & 7,5 \\
approach & Smiling (T5,T16,T37) & 3 & 7,5 \\
& Reliable (T15,T23,T2) & 2 & 5 \\
& Humble (T6,T16) & 2 & 5 \\
& Objective (T18,T36) & 2 & 5 \\
& Being egoless(T30,T36) & 1 & 2,5 \\
& Appreciatory (T1) & 1 & 2,5 \\
& Prudent(T13) & 1 & 2,5 \\
& Consistent (T15) & 1 & 2,5 \\
\hline
\end{tabular}

When Table 7 is analyzed, teachers' opinions on the approach to teachers of the leader school principal, it was observed that it was at the most $67,5 \%$ as fair. Other opinions are as follow: $27,5 \%$ politeand outgoing, $22,5 \%$ understanding and empathetic, $17,5 \%$ supportive, $7,5 \%$ smiling and reliable, $5 \%$ humble, objective and egoless, 2,5\% appreciatory, prudent, consistent and sincere. The exact quotations taken from the opinions of the teachers are presented below.

"Should be equal to all teachers, authoritative when necessary."(T4)

"Must be respectful, generous and humble."(T6)

"Treat equally to everyone, open to communication, empathetic."(T14)

"Understanding and tolerant, fair and a good listener."(T21)

"Communicate, support and fair teachers."(T32)

\section{RESULT AND DISCUSSION}

The results of the research carried out in order to examine the opinions of the school principals about leadership competencies in educational management according to the opinions of the teachers are given below.

1. The opinions of the teachers on the personality characteristics of the leader school principal by $\%$ $32,5^{\text {"ffair". }}$

2. The opinions of the teachers about the managerial characteristics of the leader school principal by $\% 30$ "fair".

3. The opinions of the teachers about the educational activities of the leader school principal by $\% 22,5$ "Supporting students".

4. The opinions of the teachers about the academic success of students of the leader school principal by $\%$ 32,5 "rewarding manager".

5. The opinions of the teachers about the social activity the leader school principal by \% 35 "care about".

6. The opinions of the teachers about the approach to teachers the leader school principal by \% 67,5 "fair".

According to the results of the research, when the Leadership Competencies of School Principals in Educational Management were examined in line with the Teachers' Views, it was stated that the principal should be a fair manager. It is stated that they treat teachers equally, do not distinguish between teachers and should not affect teachers in their own interests. It has been stated that there should be a manager who supports students and values them and does not ignore individual differences. It was stated that the 
principal should frequently reward the students by motivating them in order to increase their academic success. When the opinions of the teachers are analyzed and the approach of the school principal ,who has leadership skills, to the social activity activities is evaluated; It is determined that they should be supportive entrepreneur, behave as a role model, establish, support and encourage social and artistic works as well as sports activities. Leading school principal should put emphasis on artistic and sports activities by being supportive. He/she should provide opportunities for students to be successful in art and sportive activities and to improve themselves. He/she should be able to reveal the students' special skills by cooperating with the ones who are specialists in their fields. Finally, in order for leading school principals to be effective within the institution, they should treat equal to their employees and students, and should take a democratic and fair approach. Otherwise, principals may lose their reliability. There may be problems with respect that must be shown to them by their staff and students. School principals should be able to treat to their teachers in a sensitive way and try to understand them. In this way, it was stated by the teachers who participated in the interviews that they should guess how the teachers will perceive or feel regarding their manners and behaviours.

When the studies on the leadership competencies of school principals in educational management are examined; According to Akbaşlı and Diş (2019), school principals should be treat equally and fair towards them so that they can guide the employees. Otherwise, teachers may not trust the behavior of school principals. There may not be respected as the expect. However, principals should understand teachers by establishing empathy. The school principal should understand what the teachers think as a result of their behavior. School principals should give teachers a sense of confidence with their behavior and manners. It is an effective reason to be sincere when giving this feeling. It is an important factor for the principal to behave fairly, to support the teachers' ideas, and to value their thoughts. Erçetin (1997) who says the features expected from the school principals correctly, is being honest, not hiding his ideas, giving confidence, being determined, supportive, fearless, accessible and loyal; self-controlled, prudent and free. This also supports our research. In her/his study, Erçetin (1993) stated that school principals are the administrators who will keep the spirit of the schools alive, establish the school culture, and realize the vision of the school by taking the school to its goals. Hicks (1977) and Homans (1971) cited the behaviors of a leader to influence their employees as suggestions, being motivative, fairness, representation, trust, being good listeners, leadership, ideas, motivation, reward and collaboration. On the other hand, Baltaş (2003) explained her/his managerial characteristics and stated the characteristics that a school principle should have as follows; be consistent and honest, determined, dominate and having a good vision. These views were found to support the research. According to Turan, Yıldırım and Aydoğdu (2012), a school principal should be a good observer. By understanding the psychological status and mood of their students, they should be able to meet and support them on the situation they are in.In addition, students should be able to take part in social activities related to their interests (MEB, 2000), encourage students to support this issue. According to Glasser (1999), he stated that the success of the leader school principal will be achieved by giving an informative speech to the students at the beginning of the semester and reminding them throughout the year, by keeping the target high and encouraging the students for the target. In this context, the most important factor is to periodically remind students of the success expected and the goals set. Thus, students will be motivated to achieve success and goal, and it will be easier to reach. As with the students, the principal should remind the target set in the teachers and motivate them to ensure that the students achieve the specified goals. Şişman (2002) stated that the principal of the school, as the leader of the institution, must prepare the necessary environments for the success of students and the quality of learning. According to Argon and Dilekçi (2014), school principals working with a fair management approach have a high level of trust in teachers. For this reason, the decisions to be taken at the school are taken together by the principal and teachers. It is understood that these views overlap with the research. Akbaşli and Kavak (2008) are one of the most obvious goals of schools to provide students with their needs within the scope of their interests and abilities and to provide them with the necessary learning environments. For this reason, the students must first be accepted as different individuals and their needs must be determined. This will increase the quality of the education to be given to the students and will provide convenience to the school principals. 


\section{SUGGESTIONS}

It is possible to make suggestions to reduce the negative ratios of leadership qualifications of school principals in educational management. Based on the results of the research, the following recommendations can be made. Competence should be sought primarily in school principals. In this context, while defining school principals, existing deficiencies should be identified and efforts should be made to remove them. Priority should be given to the candidates who are trained in the field of education. In-service trainings on leadership and school management can be organized. Personality characteristics of school principals can be effective in school management. For this reason, school principals should have leadership characteristics and should not reflect their personality characteristics to the school. In other words, she/he should be a professional manager. School principals will often encounter difficulties and obstacles in school management, they must struggle against the obstacles and do not lose their excitement. School principals should work to serve them rather than expecting teachers and students to serve them at the school where they work.

Considering the results obtained from this research, school principals should determine which leadership qualities they are acting with and pay attention to their professional development in order to gain the missing leadership qualities that they need to have. In addition, it is expected that the demographic characteristics of the school principals should be taken into consideration rather than the teachers in the studies related to the leadership competencies of the school principals, and more meaningful findings will be obtained.

\section{REFERENCES}

Akbaşl1, S. \& Diş, O. (2019). Öğretmen görüşleri doğrultusunda lider okul yöneticilerinin yeterlilikleri. Uluslararası Liderlik Çalışmaları Dergisi, 2,2,s.86-102

Akbaşl1, S. \& Kavak, Y. (2008). Ortaöğretim okullarındaki okul aile birliklerinin görevlerini gerçekleştirme düzeyleri. Selçuk Üniversitesi Sosyal Bilimler Enstitüsü Dergisi,19, 1-21.

Argon, T. ve Dilekçi, Ü. (2014). Öğretmenlerin okul müdürlerinin yönetim tarzları ve kurumsal itibara yönelik algıları arasındaki ilişki. International PeriodicalFortheLanguages, LiteratureandHistory of TurkishorTurkic, 9(2), 161-181.

Arslan, H. \&Beytekin, F. (2004). İlköğretim okul müdürleri için eğitim liderliği standartlarımın araştırılması. XIII. Ulusal Eğitim Bilimleri Kurultayında sunuldu. 6-9 Temmuz. İnönü Üniversitesi, Eğitim Fakültesi, Malatya

Balc1, A. (2007). Etkili okul ve okul geliştirme.Pegem Akademi Yayınclık, Ankara.

Baltaş, A. (2003). Liderlik yetkinlikleri. Kaynak Dergisi, Sayı: 14, nisan-eylül.

Beck, L.,\& Murphy, J. (1993). Understandingtheprincipalship: Metaphoricalthemes 1920s-1990s. New York: TeachersCollege

Bursalığlu, Z. (2002). Okul yönetiminde yeni yapı ve davranış. Pegem A Yayıncılık, On üçüncü Baskı, Ankara.

Bush, T. \&Glover, D. (2003). School leadership: Conceptsandevidence. Nottingham, NationalCollegefor School Leadership.

Cerit, Y. (2008). Öğrenci, öğretmen ve yöneticilerin müdür kavrami ile ilgili metaforlara ilişkin görüşleri. Eğitim ve Bilim Dergisi, 33(147).

Duman, T \& Karagöz, S. (2016). An evaluation of Turkish teacher education system compared to other models in different countries. International Journal of Educational Research Review 1(1): 1-13.

Erçetin, Ş. Ş. (1993). Ast-üst ilişkileri (okul müdürü ve öğretmenlerin birbirlerini etkilemekte kullandikları güçler).Ankara: Şafak Matbaacıllk.

Erçetin, Ş. Ş. (1997). İlköğretim okullarında yöneticilerin vizyon geliştirmeye ilişkin tutumları. 21. Yüzyılda Liderlik Sempozyumu.

Erdoğan, İ. (2000). Okul yönetimi ve öğretim liderliği, Sistem Yayıncllı, İstanbul.

Glasser, W. (1999). Okulda kaliteli eğitim, Çeviri: Ulaş Kaplan. Beyaz Yayınları, Ankara. 
Goldberg, M. F. (2001). Leadership in education: fivecommonalities. Phi Delta KappanBloomington, Jun, Vol: 82, Issue 10, pg. 757, 5 pgs.

Gümüşeli, A. İ. (2001). Çağdaş okul müdürünün liderlik alanları. Kuram ve Uygulamada Eğitim Yönetimi Dergisi, 28, 531-548.

Hull, J. (2012). Theprincipalperspective: Full report. Retrievedfrom http://www.centerfor publiceducation.org/principal-perspective

Kalyoncu, K, (2008). İlköğretim okul müdürlerinin vizyoner liderlik özelliklerine sahip olma yeterlilikleri. (Yayımlanmamış Yüksek Lisans Tezi). Yeditepe Üniversitesi Sosyal Bilimler Enstitüsü, İstanbul.

Karagöz, S. (2018). Sadrettin Celal Antel's ten-year ministry development report: an assessment based on the divisions of educational sciences. Universal Journal of Educational Research, 6(5), 1119-1128, DOI: 10.13189 /ujer. 2018. 060533.

Karagöz, S. \& Rüzgar, M. (2020). The observations of student teachers in regard to professional qualifications of advisor teachers during teaching practicum. International Journal of Educational Research Review , 5 (2) , 141-150 . DOI: 10.24331/ijere.691323.

Law, S. \&Glower, D. (2000). Educationalleadershipandlearning. Buckingham: Open Uni. Press.

McEwan, E. (2018). Ten traits of highlyeffectiveprincipals(Çev. Necati Cemaloğlu). Ankara: Pegem Akademi.

MEB (2000). Milli Eğitim Bakanlığı İlköğretim Okulları Müdürlüğü Görev Tanımı, Tebliğler Dergisi. Sayı: 2508.

Murphy, J. (1998). What's a headfortomorrow'sprincipals. Principal Magazine, September. 3.

OECD (2009). Creatingeffectiveteachingandlearningenvironments: First resultsfrom TALIS. Paris: OESD.

Özcan, Y. (2006). “İlköğretim öğretmenlerinin iş tatmini ile yöneticileri için algıladıkları liderlik davranışı arasındaki ilişki düzeyi”. Yayımlanmamış Yüksek Lisans Tezi. Yedi Tepe Üniversitesi Sosyal Bilimler Enstitüsü.

Özden,Y. (2005). Eğitimde Yeni Değerler Eğitimde Dönüşüm. Ankara: Pegem A Yayıncılık.

Özden Y. (1998). Eğitimde dönüşüm: Yeni değer ve oluşumlar. Ankara: Pegem Yayınları.

Robinson, V. M. J., Lloyd, C. A., \&Rowe, K. J. (2008). Theimpact of leadership on studentoutcomes: An analysis of thedifferentialeffects of leadershiptypes. Educational Administration Quarterly, 44(5), 635674.

Şişman, M. (2002). Öğretim Liderliği.Pegem Yayınları, Ankara.

Taymaz, H. (2003). Uygulamalı okul yönetimi (6. Baskı). Ankara: Pegem.

Turan, S., Yıldırım, N. \& Aydoğdu, E. (2012). Okul müdürlerinin kendi görevlerine ilişkin bakış açıları. Pegem Eğitim ve Öğretim Dergisi, 2 (3), 63-76.

Ünal, M. (2012). Bilgi çağında değişim ve liderlik. Marmara Üniversitesi İktisadi ve İdari Bilimler Fakültesi Dergisi, 32(1), 297-310.

Yıldırım, A. \& Şimşek, H. (2008). Sosyal bilimlerde nitel araştırma yöntemleri: Seçkin Yayıncılık, ANKARA. 


\section{INTERVIEW FORM}

Dear Colleagues;

This study is carried out to investigate the leadership characteristics of school principals with teachers' opinions on what should happen while performing their managerial duties.There is no right or wrong answer to the questions asked within the scope of the study.Therefore, you are expected to answer the answers in line with your thoughts and teaching life.In the study, your personal information will be kept confidential and will not be shared with third parties / institutions under any circumstances. Thank you for your help and contributions.

Gender: Age: Year of Seniority:
\begin{tabular}{|c|l|}
\hline ON & TEACHER INTERVIEW QUESTIONS \\
\hline 1 & What are the personality characteristics of leading school principals from your perspective? \\
\hline 2 & What are the management features of leading school principals from your perspective? \\
\hline 3 & What are the characteristics of leading school principals regarding educational activities in your eyes? \\
\hline 4 & What are the characteristics of leading school principals regarding students' academic success? \\
\hline 5 & What are the characteristics of leading school principals regarding social activities from your perspective? \\
\hline 6 & What are the characteristics of the leading principals' approach to teachers in your view? \\
\hline
\end{tabular}

